Ilmenau University of Technology

Institute of Economics

Ilmenau Economics Discussion Papers, Vol. 26, No. 145

The Prices of Open Access Publishing: The Composition of APC across Different Fields of Sciences

Xijie Zhang, Thomas Grebel \& Oliver Budzinski

Oktober 2020

Institute of Economics

Ehrenbergstraße 29

Ernst-Abbe-Zentrum

D-98 684 Ilmenau

Phone 03677/69-4030/-4032

Fax 03677/69-4203

https://www.tu-ilmenau.de/wpo/forschung/

ISSN 0949-3859 


\title{
The Prices of Open Access Publishing: The Composition of APC across Different Fields of Sciences
}

\author{
Xijie Zhang, Thomas Grebel, Oliver Budzinski
}

\begin{abstract}
Modern media technologies paved the way to the open access movement. Instead of the traditional academic subscription and publishing model, which allowed few big publishers to charge excessive publishing fees, the open access model raises the hope for a fair system, where scientific content is freely accessible and thus the dissemination of research work becomes possible at little cost. However, previous literature pointed out that big publishers seem to be able to preserve their market power when going from the subscription-based model to the open access model. In this paper, we take a closer look at the differences across disciplines. The publication routines in Social Sciences, Physical Sciences, Life Sciences and Health Sciences differ to a substantial extent. On these grounds, we test whether there are also differences in the explanations for the article processing charges (APC) across these disciplines. For doing so, we combined various data sources such as the dataset of the "Directory of Open Access", the "OpenAPC Initiative" and the "CiteScore Metrics". Our regression results show that the differences across the four fields in terms of publication habits and endowment levels allow publishers to exploit their market power to different extents.
\end{abstract}




\section{Introduction}

In principle, the process of publishing scientific articles is the same across all scientific disciplines. After a quality check - ensured by the traditional peer-review process - the journal decides if an article can be published. Since the publishing process is a simple routine and authors, reviewers and editors are barely paid for their contributions to the scientific publication process, one may conclude that production cost should not differ much between publishers either, and neither should prices for accessing published research work. One reason why prices differ, as publishers may argue, is that journals enjoy different levels of reputation. To publish an article in a reputed journal also yields reputation to respective authors - and reputation, not the least, is what researchers eventually seek for (Bergstrom, 2001; Grebel, 2011; Smith, 2018). Accordingly the publishers can charge higher APCs.

Another reason for differences in prices may be rooted in a certain degree of market power in the scientific publishing market. Primarily libraries but also remaining subscribers pay more and more for accessing scientific journals. For dominant publishers, academic publishing has become a profitable business in recent decades (Delamothe \& Smith, 2004). Considerable merger and acquisition activities in the publishing market have aided big publishers to increase their market power and their pricing strategy of bundling famous journals with less famous ones tends to facilitate re-allocating rents from buyers to the publishers (McCabe, 2002; McCabe, 2004; Solomon \& Björk, 2012b).

Not even the era of digitalization, which has made the open access (OA) movement possible, seems to diminish publishers' market power, despite its production cost reducing effect in the publication process (Budzinski, et al., 2020). The Budapest Open Access Initiative in 2001 (Tennant, et al., 2016; Piwowar, et al., 2018) started to pursue the idea to make scientific knowledge freely accessible. To set this into practice, the payment procedure needed also a new design. Instead of subscribers paying subscription fees, it will be authors, or libraries to which they are associated with, that pay so-called article processing charges (APC) ${ }^{1}$, i.e. the price for OA publishing. However, the implicit hope that this technical change comes with a reduction in publishing cost for them has not yet been satisfied. Publishers started to adjust to this change by adapting their business model. Two strategies emerged: first, the creation of new journals, explicitly devoted to open access publishing (the so-called gold-OA journals) and, second, the development of hybrid OA options offering authors to choose between the

There is a considerable number of journals financially supported by academic institutes like universities and societies, which very often are free of charges. As our study focus is on the APC, these cases are excluded from the analysis. 
subscription model or the OA model on the level of every single paper to be published. Thus, by pursuing the latter strategy, publishers could skim the cream of both the subscription model and the OA model. Parts of the articles in hybrid journals would remain subscription based, whereas articles for which authors opted for the OA model became freely available. The hybrid model is mainly employed by incumbent publishers and hybrid journals manage to charge higher APC than their gold OA counterparts (Morrison, et al., 2015; Pinfield, et al., 2016; 2017) ; Budzinski, et al., 2020).

The variance in APC between journals is large. This holds true also among journals of big publishers. Many studies have been conducted to disentangle the different drivers of APC (Hagenhoff, et al., 2008; Solomon \& Björk, 2012a; Romeu, et al., 2014; Wang, et al., 2015; Pinfield, et al., 2016; Pinfield, et al., 2017; Schönfelder, 2018; Budzinski, et al., 2020; Yuen, et al., 2019). Reputation is one of the most frequently investigated explanatory variable. Usually proxied by journal impact factor, it takes a positive impact on APC (Schönfelder, 2018; Budzinski, et al., 2020). The largest share in APC, as Schönfelder (2018) and Budzinski, et al., (2020) show, accrues to the hybrid business model. Especially established big publishers are able to charge significantly higher APC.

In contrast to previous studies, which merely controlled for the heterogeneity between disciplines within their estimation strategy, we focus explicitly on the APC differentials between disciplines. Despite the same fundamental structure, different scientific disciplines follow quite different publication regimes in detail. Some disciplines experience abundance of funding opportunities while others have difficulty in doing so (Solomon \& Björk, 2012a; 2012b; Tenopir, et al., 2017). As a consequence, publishers with market power could try to acquire a greater share in the respective discipline's disposability of funds. A further difference lies in the availability of outlets. Some disciplines have a higher number of publication slots available in journals than in others (Buchheit, et al., 2002). Furthermore, some disciplines value preprints more for the sake of visibility, in contrast to disciplines focusing exclusively on peer-reviewed journal articles (Fry, et al., 2016). Also, importantly, not all disciplines are dominated by established and/or for-profit publishers/journals in the same way, which eventually affects APCs. Particularly in smaller disciplines non-profit publishers are prevalent (Dewatripont, et al., 2007; Gargouri, et al., 2012). All these differences, as we hypothesize, create specific conditions for incumbent publishers to adjust their rent-seeking behavior accordingly, which will also reflect in the differences in APCs across disciplines. 
In order to provide a preliminary picture, we will focus on the four main subject fields provided by Scopus which is also widely used in the literature, namely Health Sciences, Life Sciences, Physical Sciences and Social Sciences (for classification details, see Appendix 1). We will compare the difference in APC levels across these four groups. Then we test the influence of market power on APC levels. The dataset is assembled from three main sources: The Directory of Open Access Journals (DOAJ), the "OpenAPC Initiative", and the "CiteScore Metrics" of Scopus. In addition, we complete the data with information about publisher profit types and the foundation year of the publisher.

In the next section, we motivate the hypothesis we derive. Section three provides details on the data and methodology. Results are discussed in section four, followed by the limitations of our study and a conclusion in section five.

\section{Objectives and Hypotheses}

The objective of this study is to test, to what extent established publishers exploit their market power by raising the APC above basic production cost in the four selected disciplines.

Research question: How does market power contribute to APC differences across discipline fields?

Many studies report that there is an obvious variance of APCs across disciplines. Journals from Life and Health Sciences appear to be levying the highest APC and Social Sciences seems to be offering the most favorable price for OA publishing (Hagenhoff, et al., 2008; Solomon \& Björk, 2012a; Solomon \& Björk, 2012b; Björk \& Solomon, 2015; Schönfelder, 2018). The reasons behind this variance can be manifold, but results from previous studies suggest that market power should play a considerable role in determining APC levels (Schönfelder, 2018; Budzinski, et al., 2020). Suppose the market of academic publishing is sufficiently competitive and publishers do not possess much market power within an individual subject field, then APC should be around the level of the production cost of publishing. With digitization, the production process of a scientific article should be similar across disciplines, which means that prices (APCs) should be around the same level as well, while taking all remaining drivers of APC into account such as differences in reputation. If they nevertheless differentiate their APC levels, publishers have market power and exploit it to maximize their profits.

Since Health Sciences and Life Sciences enjoy access to higher resources funding, inter alia, publication prices (like submission fess but also like APCs), the authors from these fields may 
display a higher willingness-to-pay, followed by Physical Sciences (Solomon \& Björk, 2012a). Conversely, authors of Social Sciences have significantly less financial support, which forces them to prefer cheaper publication opportunities. In other words, they have a lower willingness-to-pay. Generally, publishing in a peer-review OA journal has two benefits: one is the prestige arising from such a journal; the other is the potentially high visibility thanks to free access (boosting citations). Both the prestige of the publication outlet and the number of citations of one's work are important career mechanisms in science. Most of prestigious journals delivering high reputation are incumbent outlets, having been in the market long before the OA movement started, because reputation-building takes time (Suber, 2002; Liu, 2005). As a consequence, the more prestigious journals are usually paid-hybrid-OA - and the more expensive ones as former studies found reputation to be a driving-factor for APC (Solomon \& Björk, 2012a; Solomon \& Björk, 2012b; Wang, et al., 2015; Pinfield, et al., 2017; Schönfelder, 2018). Thus, publishing OA in journals offering high reputation in general incurs considerable costs to the authors. By contrast, publishing with the closed-access option, authors still enjoy the journals' prestige but without bearing any cost.

The disadvantage of publishing with the subscription-only-access option - the danger of low visibility - may be alleviated by freely available preprints (a form of free open access). These are earlier versions of papers published in peer-reviewed journals, usually without the latest review-based changes and not in the journal-style edition. One of their functions is to bridge the time-consuming process of peer-reviewed publication (which can take several years) and create an immediate availability of newest research - though having not yet passed the (often lengthy) quality control mechanisms of peer-review (so-called working papers or discussion papers). However, preprints may also alleviate the disadvantage of publishing with the subscription-only-access option: if, at the end of the process, a publication in a subscription-based accessible prestigious journal co-exists with a freely available preprint, then reputation and visibility can be achieved without the authors having to pay a high (APC) price. Thus, the combination of closed-access publication and free preprint may be an imperfect substitute for OA publishing in the eyes of authors. At the same time, the preprints also represent an alternative for readers wanting access to the papers, which should lower the market power of the journal publishers.

In the context of this study, it is important to consider that preprint practices differ across disciplines. Scholars in some disciplines of Social Sciences favor preprints and even cite preprints in their papers (Whitley, 2000; Fry, et al., 2016). By contrast, in Health and Life Sciences, articles are only published in peer-review journals and remain invisible before 
(Whitley, 2000; Fry, et al., 2016). Hence, while the combination of preprints and closedaccess journal publications may represent an acceptable option from the perspective of Social Sciences authors, the expensive OA option of a prestigious journal may be seen as an important and necessary enhancement of the closed-access option for scholars in Health Sciences and Life Sciences - particularly given the good availability of (external) funding for APCs. If established publishers extract supracompetitive rents due to market power, APCs should be observed the highest in Health Sciences and Life Sciences and lowest in Social Sciences due to the field-specific situations. Market power should have the strongest impact on APCs in Health Sciences and Life Sciences, whereas it should be lowest in Social Sciences.

Hypothesis: Market power has a higher impact on APCs in Health Sciences and Life Sciences than in Physical Sciences and Social Sciences.

\section{Data and Method}

To test our hypothesis, we conduct multivariate regressions, taking the following variables into account: market power (as our prime interest), journal reputation, citations, number of articles per journal, profit types (non-profit/for-profit), and publisher age. We construct market power from two variables, namely hybrid and big publisher. As pointed out, a hybrid journal is a journal that offers a gold-OA publishing option, while keeping the traditional subscription model as a default. As reported, hybrid journals, which usually belong to incumbent publishers, charge higher APCs in their OA option than gold journals (Morrison, et al., 2015; Pinfield, et al., 2016; 2017). Due to indirect network effects, when looking at the publishing market as a two-sided market (Jeon \& Rochet, 2010; Armstrong, 2015; McCabe \& Snyder, 2007; 2018), authors respond more elastically to the price for OA publishing than readers for accessing an article (stronger indirect network effect from authors to readers than vice versa). Thus, the publisher as a platform would actually like to charge readers and cross-subsidize authors. Consequently, the ability to extract rents from the market is more limited in the OA model.

Additionally, with open access, for-profit publishers cannot enjoy excess rents by subscription bundles anymore. Publishers enjoying market power experiences incentives to keep as many authors and readers in the old system as possible. Introducing a hybrid version allows for offering authors a choice to stick to the old, closed-access model or pay for getting OA. The incentive for the publisher is then to set APCs on a high level in order to (i) push authors back into the closed-access model and (ii) reap revenues from those authors (or their financial 
backers) displaying a high willingness-to-pay in order to compensate for the loss of supracompetitive rents. Thus, established publishers may keep their revenue stream up while, at the same time, hampering the attractiveness of OA publishing. By contrast, publishers of gold OA journals need to earn all their revenues through OA and cannot afford to restrict their offers to authors with a high willingness-to-pay (as long as they cannot price-discriminate between authors according to their individual willingness-to-pay). Therefore, we consider hybrid journals as publishers' attempt to sustain their market power (Budzinski et al., 2020). This should be the case also for the top five publishers above all. Across all disciplines, they own more than 45 per cent of the total number of articles according to the data of "CiteScore Metrics Scopus". ${ }^{2}$ Market concentration in a field also is a relevant factor in driving APCs. However, it also is a fixed effect in the respective disciplines, for which we employ dummies. Including the fields as dummy variables, we could explain more variance in APCs than with market concentration. This is also one of the findings in Budzinski et al. (2020).

To proxy reputation, as one of the further drivers of APC, we use the Source-Normalized Impact per Paper (SNIP) from Scopus. In order to see the field-specific effects of market power, interaction terms of each field with hybrid and each field of big publishers are added, e.g. Health Sciences $x$ hybrid, Health Sciences $x$ big publishers. Journal reputation (SNIP), citation, number of articles, and publisher age are cardinal variables. Hybrid (hybrid or gold), big publishers (big or not), profit type (for-profit or non-profit) are dichotomous variables. Fields are four dummy variables (Health Sciences, Life Sciences, Physical Sciences, and Social Sciences).

In the following, we briefly describe the three datasets we use from DOAJ, "OpenAPC Initiative" and Scopus.

\section{DOAJ}

From DOAJ, we extract the information of the OA type gold, the publisher and the APC of gold OA journals. DOAJ is an online gold OA journal directory (https://doaj.org/). It is a cross-sectional journal-level dataset with 13,436 entries. Hence, all data entries are considered as the most updated information. Any journal found in DOAJ is counted as a gold OA journal. Entries with no APC or zero APC are excluded. After excluding the data, there are 3,547 titles left. As DOAJ is a global repository, APCs are registered with different currencies. We employ the Purchasing Power Parity (PPP) from the Organization for Economic Co-operation and Development (OECD) to convert APC into USD.

2 This is the count of big publishers according to the CiteScore Metrics Scopus database from 2011 to 2018. 


\section{"OpenAPC Initiative”}

From the "OpenAPC Initiative", we obtain the information about the kind of OA journal (hybrid vs. gold) and the value of APC. The "OpenAPC Initiative" is an open source project collecting APC information offered by participating universities and research institutions (https://www.intact-project.org/openapc/). It is located at Bielefeld University Library, supported by German Research Foundation and the Federal Ministry of Education Research. By 2019, it contains information of 81,293 articles from 2005 to 2019 contributed by 241 universities and institutes. Unfortunately, the "OpenAPC Initiative" does not provide a balanced panel although the database contains repeated cross sections. In order to produce a journallevel cross-sectional data of 2018, the mean APC is calculated. We converted APCs from originally EUR into USD using PPP from OECD.

\section{"CiteScore Metrics Scopus”}

We keep the information of SNIP, number or articles, citations and subject fields from "CiteScore Metrics Scopus". The data is downloaded from Scopus' website (https://www.scopus.com/sources). It is a panel data of 52,531 journals from 2011 to 2018. Since we have to turn the longitudinal data into a cross section in the year of 2018, we take the mean of SNIP, the number of articles and citations are summed up. If there is any unmatching information of publishers, we select the latest and the most frequent information. Finally, 25,006 observations remain.

\section{"Profit type and publisher age"}

The information of publisher profit types and the years of establishment are collected manually from publishers' websites. Publisher age is calculated by deducting the establishment year with 2018.

Finally, we merge the data of DOAJ, "OpenAPC Initiative" and "CiteScore Metrics Scopus" by ISSN, the information of publisher profit types and the foundation year of publishers by the publisher information. After merging the different data sources, the final database includes 2,887 titles.

In order to perform our analysis, we firstly run four separate regressions for each of the four fields to see how the variables of market power perform in each field. Secondly, we run the combined model by including the four fields as dummy variables. Thirdly, to see the marginal effects of market power in different subject fields, we add another model where we interact the variable market power with the four subject fields, respectively. 


\section{Results}

Table 1. Descriptive statistics.

\begin{tabular}{llllll}
\hline & Obs. & Mean & Std. Dev. & Min. & Max. \\
\hline APC & 2,887 & $2,162.97$ & $1,314.41$ & 12 & $7,501.93$ \\
SNIP & 2,837 & 1.09 & 0.72 & 0 & 8.75 \\
Hybrid & 2,887 & 0.60 & 0.49 & 0 & 1 \\
Age & 2,565 & 134.54 & 89.78 & 6 & 500 \\
For-profit & 2,571 & 0.83 & 0.38 & 0 & 1 \\
Citations & 2,887 & $8,675.4$ & $25,324.8$ & 0 & 469,880 \\
No. of articles & 2,887 & $2,678.8$ & $5,538.2$ & 1 & 124,290 \\
\hline
\end{tabular}

Table 1 shows the descriptive statistics. Since we collected the information about age and profit orientation of publishers from their websites, we had to exclude publishers without a searchable website from out study. The average APC of our dataset is 2,163 USD. The minimum is 12 USD while the most expensive outlet reaches 7,502 USD showing a big variance in the APCs among journals. The mean SNIP is 1, the difference between the highest score and the lowest is 8.75 . The gap between highest ranked journal and lowest is almost 9 scores. On average every arcticle in the dataset is cited once, but there are also journals included which articles are never cited (0) and others which articles are cited on average almost 9 times. The publishers range from 6 years old to 500 years old with an average of 135 years old, which demonstrates that most of the publishers in our data are not that young. Citations and number of articles are the sum of the years 2001 to 2018. Both of them contain huge variance, too. In our dataset, 60 per cent of the titles are hybrid journals and 83 per cent are forprofit journals. Commercial publishers and big publishers seem to take up the majority of the journals.

Table 2. ANOVA of APC, SNIP, age, citations and number of articles by subject fields.

\begin{tabular}{llllll}
\hline & Social Sciences & Life Sciences & $\begin{array}{l}\text { Physical } \\
\text { ences }\end{array}$ & $\begin{array}{l}\text { Sci- Health } \\
\text { ences }\end{array}$ & $\begin{array}{l}\text { Sci- } \\
\text { F-Stat. }\end{array}$ \\
\hline N & 475 & 754 & 851 & 799 & \\
APC & $1,958.7$ & $2,359.5$ & $2,005.6$ & $2,276.8$ & $15.76^{* * *}$ \\
SNIP & 1.03 & 1.06 & 1.2 & 1.03 & $14.13^{* * *}$ \\
Age & 155.4 & 136.2 & 128.0 & 126.6 & $10.45^{* * *}$ \\
Citations & $1,425.5$ & $10,741.2$ & $13,058.2$ & $6,396.9$ & $25.89^{* * *}$ \\
No. of articles & 867.1 & $2,871.2$ & $3,853.2$ & $2,333.5$ & $31.95^{* * *}$ \\
\hline
\end{tabular}

${ }^{* * *} \mathrm{p}<0.001,{ }^{* *} \mathrm{p}<0.01, * \mathrm{p}<0.05$

Note: the numbers in the table represent mean APC, SNIP, age, citations and number of articles within each subject field. 
The means of APC, SNIP, publisher age, citations and number of articles in each discipline are presented in Table 2. Life Sciences charges the highest APC, followed by Health Sciences and Physical Sciences, while Social Sciences comes in the last place., which is consistent with the study of Solomon and Björk (2012a), who report that Life Sciences and Health Sciences enjoy lavish grants and funding resources. Physical Sciences demonstrates the highest SNIP, which does not comply with the description in previous studies, which, for example, claim that Health Science performs best in SJR (Miguel, et al., 2011; Ennas \& Di Guardo, 2015) and JCR (Giglia, 2010; Gumpenberger, et al., 2013). Physical Sciences have the most citations and number of articles in 8 years, which goes in the same direction as SNIP. The average age of publishers is more or less the same across fields with the exception of Social Sciences having publishers about 20 years older than the others.

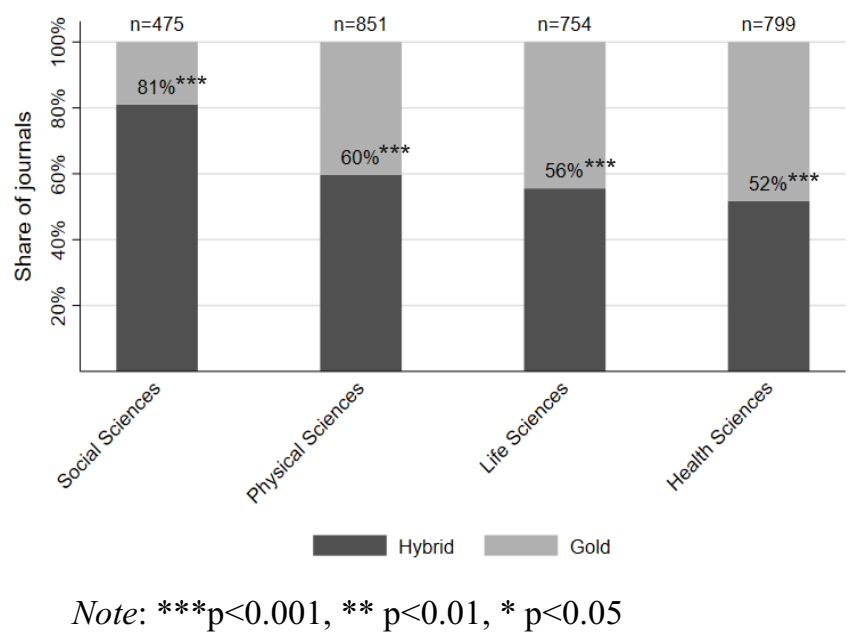

a.

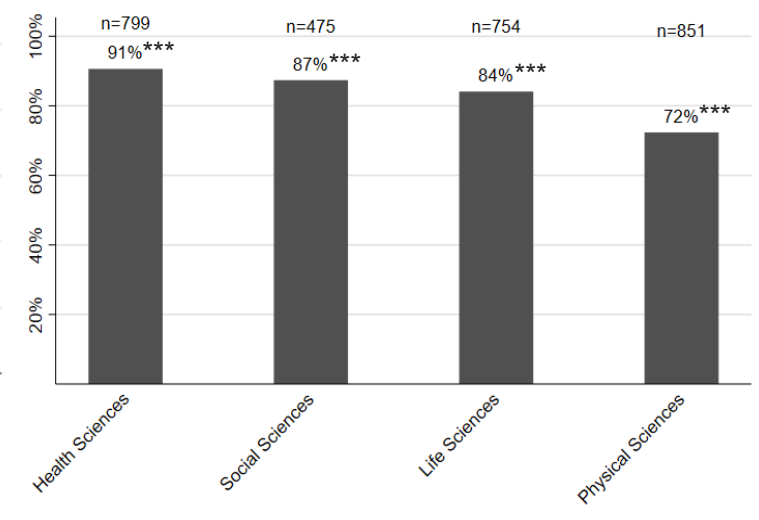

b.

Fig. 1. Shares of hybrid journals (a.) and for-profit journals (b.) in four subject fields. 
Table 3. Shares of hybrid journals in for-profit journals.

\begin{tabular}{llll}
\hline & $\begin{array}{l}\text { For-profit } \\
\text { Gold }\end{array}$ & Hybrid & Total \\
\hline \multirow{2}{*}{ Social Sciences } & 42 & 318 & 360 \\
& $12 \% * * *$ & $88 \% * * *$ & $100 \%$ \\
\hline \multirow{2}{*}{ Life Sciences } & 235 & 331 & 566 \\
\hline Physical Sciences & $42 \% * * *$ & $58 \% * * *$ & $100 \%$ \\
\hline \multirow{2}{*}{ Health Sciences } & 239 & 308 & 547 \\
& $44 \% * * *$ & $56 \% * * *$ & $100 \%$ \\
\hline \multirow{2}{*}{ Total } & 308 & 348 & 656 \\
& $47 \% * * *$ & $53 \% * * *$ & $100 \%$ \\
\hline
\end{tabular}

Note: ${ }^{* * *} \mathrm{p}<0.001, * * \mathrm{p}<0.01,{ }^{*} \mathrm{p}<0.05$

With 81 per cent, Social Sciences has the largest share of hybrid journals, followed by Physical Sciences with a share of 60 per cent (see Fig. 1a), Life Sciences and Health Sciences with a bit less but still above 50 per cent. By contrast, shown in Fig. 1b, Health Sciences has the highest share of for-profit journals, which is 91 per cent. The lowest with a share of 72 per cent is Physical Sciences. The shares of hybrid journals and for-profit journals seem to be quite close in Social Sciences (81 per cent and 87 per cent, respectively) and Physical Sciences (60 per cent and 72 per cent, respectively). Both the share of hybrid journals and the share of for-profit journals across four discipline fields are examined with $\mathrm{Chi}^{2} \mathrm{Test}$, and both have the p-values less than 0.1 per cent, which means both shares are significantly different across four fields.

In order to see, if the journals employing the hybrid model and the ones belonging to forprofit publishers overlap, we make a cross-table of discipline fields by OA models among forprofit journals (shown in Table 3). The majority of for-profit journals are using hybrid OA model in all four fields. As it is indicated in Fig. 1, the biggest overlap is in Social Sciences which accounts for 88 per cent. The significant result of a $\mathrm{Chi}^{2}$ Test means the shares of forprofit journals applying hybrid model are significantly different across four fields. 


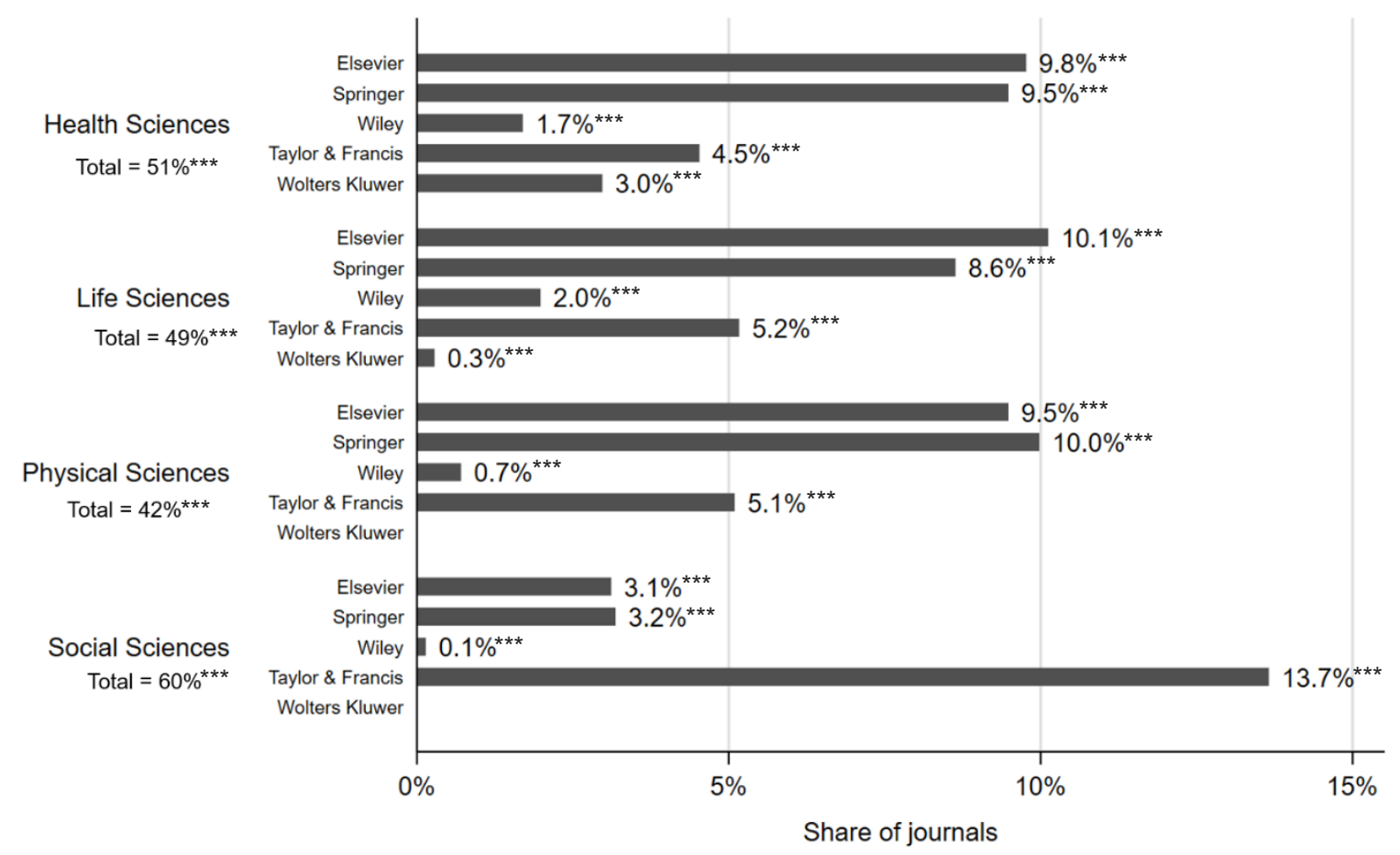

Note: $* * * \mathrm{p}<0.001, * * \mathrm{p}<0.01, * \mathrm{p}<0.05$. The percentages of the left-hand side are calculated based on the samples in each field respectively, while the percentages on the right-hand side are based on the total sample.

Fig. 2 Shares of journals belonging to the big publishers in each field.

Fig. 2 displays the compositions of the top five publishers in each subject field. On the lefthand side, we depict the shares of journals belonging to the top five publishers within each field (calculated within the observations of each field), on the right-hand side, the shares belonging to each top five publisher and each field respectively (the numbers of the bar labels are calculated based on the total observations of big publishers). Hence, we have 20 subgroups (5 publishers $\mathrm{x} 4$ fields). All the shares are examined with $\mathrm{Chi}^{2}$ Test $(\mathrm{p}<0.001)$ and it shows the shares of journals owned by top five publishers are significantly different across four fields, as well as the shares of journals belonging each big publisher differ significantly across four fields. On the left-hand side, Social Sciences has the highest share of journals belonging to the big publishers (60 per cent), which might also be the case, because this discipline has the highest share of hybrid journals. This result, at first glance, appears to be in conflict with the existing literature of Larivière et al. (2015), who, however, focus on academic journals in general rather than on OA publishing. Regarding the shares of journals belonging to the 20 subgroups (see right-hand side in Fig. 2), the highest share are taken by journals of Taylor \& Francis in Social Sciences (13.7 per cent). The journal portfolios of Springer and 
Elsevier are quite similar. Both hold journals distributed evenly across Life Sciences, Health Sciences and Physical Sciences, with around 10 per cent each. Wiley and Wolters Kluwer own fewer journals than the remaining three big publishers. Wiley concentrates mostly on Health Sciences and Life Sciences. Wolters Kluwer is a company providing diversified services in various industries but only focuses on the clinical area when it comes to research. We did not find any journals in Physical Sciences or Social Sciences from this publisher.

Table 4. Correlation matrix.

\begin{tabular}{|c|c|c|c|c|c|c|c|c|}
\hline & APC & SNIP & Hybrid & $\begin{array}{l}\text { Big publish- } \\
\text { ers }\end{array}$ & Age & Citations & $\begin{array}{l}\text { No. of } \\
\text { article }\end{array}$ & For-profit \\
\hline APC & 1.00 & & & & & & & \\
\hline SNIP & $0.41^{*}$ & 1.00 & & & & & & \\
\hline Hybrid & $0.62^{*}$ & $0.30^{*}$ & 1.00 & & & & & \\
\hline Big publishers & $0.35^{*}$ & $0.12 *$ & $0.31^{*}$ & 1.00 & & & & \\
\hline Age & $0.26^{*}$ & $0.13^{*}$ & $0.23^{*}$ & $0.22 *$ & 1.00 & & & \\
\hline Citations & $0.23 *$ & $0.32 *$ & $0.19^{*}$ & -0.04 & $0.04 *$ & 1.00 & & \\
\hline No. of article & $0.17 *$ & $0.15^{*}$ & $0.18^{*}$ & -0.04 & 0.02 & $0.77^{*}$ & 1.00 & \\
\hline For-profit & $-0.07^{*}$ & $-0.20^{*}$ & $-0.12 *$ & $0.50^{*}$ & $-0.32 *$ & $-0.24 *$ & $-0.20^{*}$ & 1.00 \\
\hline
\end{tabular}

Note: * denotes the p-value is at least less than 0.05 .

Compatible with the research of Budzinski et al. (2020) and Schönfelder (2018), the variables impact factor (SNIP), hybrid, and big publishers positively correlate with APC (see Table 4). Age, citations and the number of articles all show positive relationships with APC as well. However, for-profit seems to be negatively correlating with APC and hybrid, even though the coefficients are rather small, -0.07 and -0.12 , respectively. The connection between citations and big publishers, as well as the relation between number of articles and big publishers are not significant. The strongest correlation in Table 4 is between citations and the number of articles (0.77).

Six regression models are presented in Table 5. The first four models are regressions run for each field individually, i.e. Social Sciences (SS), Life Sciences (LS), Physical Sciences (PS) and Health Sciences (HS), having sample sizes of 408, 662, 750 and 697. Model 1 to 4 are using sub-samples of each field. Model 5 (Four fields) and Model 6 (With interaction terms) use the pooled sample including the four discipline dummies. In order to see the marginal effects of market power in each field, we include the interacted variables in model 6 . In the models with the discipline dummies (model 5 and 6), Social Sciences serves as the base category. 
Table 5. Regression table.

\begin{tabular}{|c|c|c|c|c|c|c|}
\hline & $\mathrm{SS}$ & LS & PS & HS & $\begin{array}{l}5 \\
\text { Four } \\
\text { fields } \\
\end{array}$ & $\begin{array}{l}6 \\
\text { With interaction } \\
\text { terms }\end{array}$ \\
\hline Hybrid & $\begin{array}{l}1,202 * * * \\
(153.31)\end{array}$ & $\begin{array}{l}1,402 * * * \\
(82.38)\end{array}$ & $\begin{array}{l}1,138 * * * \\
(75.70)\end{array}$ & $\begin{array}{l}1,177 * * * \\
(81.40)\end{array}$ & $\begin{array}{l}1,216^{* * *} \\
(44.56)\end{array}$ & $\begin{array}{l}1,110 * * * \\
(148.21)\end{array}$ \\
\hline Big publishers & $\begin{array}{l}374.9 * * * \\
(130.34)\end{array}$ & $\begin{array}{l}470.5 * * * \\
(101.88)\end{array}$ & $\begin{array}{l}449.1 * * * \\
(100.16)\end{array}$ & $\begin{array}{l}483.6 * * * \\
(89.99)\end{array}$ & $\begin{array}{l}397.4 * * * \\
(52.05)\end{array}$ & $\begin{array}{l}21.46 \\
(105.01)\end{array}$ \\
\hline LS x Big pub. & & & & & & $\begin{array}{l}1,081 * * * \\
(109.88)\end{array}$ \\
\hline PS x Big pub. & & & & & & $\begin{array}{l}421.6 * * * \\
(79.04)\end{array}$ \\
\hline HS x Big pub. & & & & & & $\begin{array}{l}994.9 * * * \\
(78.54)\end{array}$ \\
\hline Life Sciences & & & & & $\begin{array}{l}820.0 * * * \\
(61.18)\end{array}$ & \\
\hline Physical Sciences & & & & & $\begin{array}{l}336.1 * * * \\
(61.06)\end{array}$ & \\
\hline Health Sciences & & & & & $\begin{array}{l}822.2 * * * \\
(60.73)\end{array}$ & \\
\hline SNIP & $\begin{array}{l}-128.5 \\
(118.58)\end{array}$ & $\begin{array}{l}297.2 * * * \\
(72.25)\end{array}$ & $\begin{array}{l}154.7 * * * \\
(44.75)\end{array}$ & $\begin{array}{l}636.2 * * * \\
(61.74)\end{array}$ & $\begin{array}{l}378.8 * * * \\
(29.07)\end{array}$ & $\begin{array}{l}368.1 * * * \\
(29.03)\end{array}$ \\
\hline For-profit & $\begin{array}{l}-1,077 * * * \\
(217.87)\end{array}$ & $\begin{array}{l}223.6 \\
(142.46)\end{array}$ & $\begin{array}{l}42.66 \\
(110.70)\end{array}$ & $\begin{array}{l}-321.3 * \\
(164.01)\end{array}$ & $\begin{array}{l}-26.59 \\
(72.16)\end{array}$ & $\begin{array}{l}-102.6 \\
(75.39)\end{array}$ \\
\hline Citation & $\begin{array}{l}0.142 * * * \\
(0.04)\end{array}$ & $\begin{array}{l}0.013 * * * \\
(0.00)\end{array}$ & $\begin{array}{l}0.003 * * \\
(0.00)\end{array}$ & $\begin{array}{l}-0.004 \\
(0.01)\end{array}$ & $\begin{array}{l}0.003 * * * \\
(0.00)\end{array}$ & $\begin{array}{l}0.004 * * * \\
(0.00)\end{array}$ \\
\hline No. of article & $\begin{array}{l}-0.330^{* * *} \\
(0.10)\end{array}$ & $\begin{array}{l}-0.029^{*} \\
(0.02)\end{array}$ & $\begin{array}{l}-0.002 \\
(0.01)\end{array}$ & $\begin{array}{l}0.031 \\
(0.02)\end{array}$ & $\begin{array}{l}-0.0002 \\
(0.01)\end{array}$ & $\begin{array}{l}-0.0003 \\
(0.01)\end{array}$ \\
\hline Publisher age & $\begin{array}{l}1.836 * * * \\
(0.65)\end{array}$ & $\begin{array}{l}1.140 * * \\
(0.49)\end{array}$ & $\begin{array}{l}1.092 * * \\
(0.46)\end{array}$ & $\begin{array}{l}0.770 \\
(0.49)\end{array}$ & $\begin{array}{l}1.555 * * * \\
(0.25)\end{array}$ & $\begin{array}{l}1.312 * * * \\
(0.26)\end{array}$ \\
\hline Constant & $\begin{array}{l}1,663 * * * \\
(280.02)\end{array}$ & $\begin{array}{l}695.9 * * * \\
(166.63)\end{array}$ & $\begin{array}{l}798.0 * * * \\
(129.34)\end{array}$ & $\begin{array}{l}986.7 * * * \\
(186.92)\end{array}$ & $\begin{array}{l}126.8 \\
(98.52) \\
\end{array}$ & $\begin{array}{l}596.2 * * * \\
(167.53)\end{array}$ \\
\hline Observations & 408 & 662 & 750 & 697 & 2,517 & 2,517 \\
\hline R-squared & 0.316 & 0.518 & 0.435 & 0.531 & 0.450 & 0.459 \\
\hline R2 (adj) & 0.304 & 0.513 & 0.430 & 0.526 & 0.448 & 0.455 \\
\hline
\end{tabular}

Standard errors in parentheses

$* * * p<0.01, * * p<0.05, * p<0.1$

Note. Since coefficients of the interaction terms field $x$ hybrid are not significant, they are not shown on the table.

As mentioned, we interpret market power with the influence of two variables, hybrid and big publishers. Hybrid displays a positive effect across all the models and turns out as the strongest effect among all the variables. In the case of Life Sciences, hybrid has the biggest impact on APCs. Authors pay about 1,402 USD (see model LS) more in comparison to a gold OA journal. Looking at Model 6, a hybrid journal charges 1,110 USD more for OA publications than a gold journal, on average. However, the field-specific marginal effect of hybrid is not significant. It means that hybrid has the strongest impact on APC across all fields with no discrimination. 
The publication fee, as suggested by the literature, is the lowest in Social Sciences (compare model 5). Health Sciences and Life Sciences exhibit the highest mean APC with 822 USD and 820 USD more than Social Sciences, respectively. The average APC of Health Science is $949 \operatorname{USD}(822+127=949$ USD $)$ and Life Sciences is 947 USD $(820+127=947$ USD $)$.

The impact of big publishers is significant throughout model 1 to model 5. Looking at the four fields separately, a journal from one of the top five publishers (i.e. Elsevier, Springer, Wiley, Taylor \& Francis, and Wolters Kluwer) in Social Sciences tends to bring up the APC by 375 USD (see model 1), which refers to 60 per cent of the journals in Social Sciences (see Fig. 2), while in Health Sciences, it would become 51 per cent of the journals requesting 484 USD more when compared to the rest (see model 4 and Fig. 2). Including all fields, journals owned by top five big publishers are 397.4 USD more expensive (see model 5). From Model 6 , we can see the marginal effect of big publishers in each field. Journals of big publishers charge the most in Health Sciences and Life Sciences, 1,591 USD $(995+596=1,591$ USD) and 1,677 USD $(1,081+596=1,677$ USD), respectively. In Physical Sciences, big publishers are still able to charge 422 USD more compared to the base category, i.e. Social Sciences no big publisher. To conclude, market power, as proxied by the variables hybrid and big publishers, plays the biggest role in Health and Life Sciences, the lowest in Social Sciences. In other words, the differences across the four fields in terms of publication habits and endowment levels allow publishers to exploit their market power to different extents.

\section{Discussion and Conclusions}

The study investigates whether publishing giants adjust their market power-based rentseeking strategies according to the special circumstances in different disciplines, in particular (i) different willingness-to-pay by authors because of differences in discipline endowment (funding) and (ii) the relevance of the visibility of journal articles because of the (non-) existence of (imperfect) substitutes for access (preprints). The results suggest that Health Sciences and Life Sciences, i.e. the fields with the highest financial endowments and a lack of substitutes for accessing non-OA papers, display the highest APC levels, whereas Social Sciences, i.e. a field with a lower willingness-to-pay and widespread use of preprints shows significantly lower prices. Thus, the discipline-specific effect of market power on APCs is the smallest in Social Sciences and the strongest in Health Sciences and Life Sciences, supporting our hypothesis. In addition, we could show - in line with the existing literature - that the strategy to amend the traditional subscription-based model with an OA option, i.e. to create so-called 
hybrid journals, pays off for established publishers. They seem to be able to convey their market power from the traditional to the new world of digital publication.

To what extend powerful publishers can score supracompetitive rents depends, inter alia, on some features of the publishing markets in the respective disciplines. For instance, publishers with market power manage to exploit the superior funding opportunities that exist in some disciplines. In Health Sciences and Life Sciences, researchers receive substantially more financial support compared to Social Sciences. This implies that academic authors in these fields can at least partly pass the market power rents levied on them by publishers through to the funding institutions. This pass-through possibility increases the willingness to pay expensive APCs of authors in these fields. Moreover, in these fields, researchers also lack good substitutes for paid-OA publishing when it comes to creating visibility of and access to their work. Particularly in Social Sciences, the preprint culture limits the market power of the publishers because other researchers may use an imperfect substitute to accessing the journal article.

As our empirical exercise shows, in spite of roughly homogeneous production costs of publishing OA journals across publishers, which we believe to be a legitimate assumption, APC to be paid by libraries/authors vary significantly across disciplines and publishers, which to a large extent can be attributed to their market power - even when controlling for reputation.

This insight should be considered when designing the institutional framework for this market. Due to the buyers in the old model being mostly university libraries and due to authors being predominantly university researchers - both with a significant share of public funding (although differing across countries) - taxpayer money plays an important role in this market. If governments and regulators want to promote OA publishing of scientific insights, they will likely look to support authors from public research organizations to pay APCs - as it is already happening or being negotiated in many countries. However, while this may succeed in triggering more authors to choose the OA option in hybrid journals, it also makes authors less price sensitive: if someone else pays the price, the willingness-to-pay by the authors increases. Thus, financial support for authors publishing in hybrid OA journals also contributes to prolonging and maintaining supracompetitive rents for commercial academic publishers. The question is, then, whether taxpayers really should finance rents and profits of academic publishers.

So, do the goals of promoting OA publishing and preventing market power rents in the market for academic publishing contradict each other (creating a dilemma situation)? A way forward 
could be to support authors in paying APCs for gold OA journals as well as for journals of non-for-profit academic publishers. The first do not look to recover lost rents from the old model and experience stronger incentives to respond to competitive pressure, also because they often cannot build upon a persistent reputation advantage. The second look more for covering their costs then for creating profits. And in contrast to the large majority of gold OA journals, some journals from non-commercial academic publishers actually enjoy high reputation. Financial support for OA options of commercial academic publishers could then be limited to what the other two types charge. Another avenue would be to erode the reputation advantage that many hybrid journals enjoy vis-à-vis gold OA journals by helping the latter to build up competitive reputation. With roughly equal reputation (across journal types, not necessarily across journals), authors are more likely to go for the better prices, i.e. lower APCs, creating an effective competition. However, this may be a long process and it is rather unclear how this may work in detail. Similarly, the academic communities who provide non-paid-for input to this market as authors, editors and reviewers anyway, may engage stronger in developing and publishing online-only academic journals without commercial interest. In the digital online world, moreover, alternative forms of peer-reviewed outlets and repositories may create new competitive pressure for traditional types of academic journals.

So far, the insights we gained in this study lead us to conclude that the transformation toward open access publishing fails to change relevant deficits of the old system when creating a new system, in which scientific knowledge is publicly accessible without any pay walls and barriers. Big publishers remain powerful also in the new world of open access publishing and there is indication that they are able to leverage their market power into the new system, perhaps even corroborated by taxpayer money.

\section{Acknowledgement}

We thank Jens Wolling for valuable comments to an earlier version of this paper. 


\section{Reference}

Armstrong, M., 2015. Opening access to research. The Economic Journal, 125(586), pp. F1F30.

Bensman, S., 2011. The structure of the library market for scientific journals: The case of chemistry. Library Resources \& Technical Services, 40(2), pp. 145-170.

Bergstrom, T., 2001. Free labour for costly journals?. Journal of Economic Perspectives, 15(4), pp. 183-198.

Björk, B.-C. \& Solomon, D., 2012. Open access versus subscription journals: a comparison of scientific impact. BMC medicine, 10(1), p. 73.

Björk, B.-C. \& Solomon, D., 2014. Developing an effective market for open access article processing charges, London: Jisc, Research Libraries UK, Research Councils UK, the Wellcome Trust, the Austrian Science Fund, the Luxembourg National Research Fund, and the Max Planck Institute for Gravitational Physics.

Björk, B.-C. \& Solomon, D., 2015. Article processing charges in OA journals: relationship between price and quality. Scientometrics, 103(2), pp. 373-385.

Buchheit, S., Collins, D. \& Reitenga, A., 2002. A cross-discipline comparison of top-tier academic journal publication rates: 1997-1999. Journal of Accounting Education, 20(2), pp. 123-130.

Budzinski, O., Grebel, T., Wolling, J. \& Zhang, X., 2020. Drivers of article processing charges in open access. Scientometrics, pp. 1-22.

Delamothe, T. \& Smith, R., 2004. Open access publishing takes off. BMJ, 328(1), pp. 1-3.

Dewatripont, M., Ginsburgh, V., Legros, P. \& Walckiers, A., 2007. Pricing of scientific journals and market power. Journal of the European Economic Association, 5(2-3), pp. 400-410.

Ennas, G. \& Di Guardo, M. C., 2015. Features of top-rated gold open access journals: An analysis of the scopus database. Journal of Informetrics, 9(1), pp. 79-89.

Fry, J., Spezi, V., Probets, S. \& Creaser, C., 2016. Towards an understanding of the relationship between disciplinary research cultures and open access repository behaviors. ournal of the Association for Information Science and Technology, 67(11), pp. 2710-2724.

Gargouri, Y. et al., 2012. Green and gold open access percentages and growth, by discipline. s.l., s.n., p. arXiv:1206.3664.

Giglia, E., 2010. The impact factor of open access journals: data and trends. s.1., Hanken School of Economics, pp. 17-39. 
Grebel, T., 2011. Innovation and health: Theory, methodology and applications. Cheltenham: Edward.

Gumpenberger, C., Ovalle-Perandones, M.-A. \& Gorraiz, J., 2013. On the impact of gold open access journals. Scientometrics, 96(1), pp. 221-238.

Hagenhoff, S., Blumenstiel, M. \& Ortelbach, B., 2008. An empirical analysis of the amount of publication fees. Serials Review, 34(4), pp. 257-266.

Jeon, D. \& Rochet, J., 2010. The pricing of academic journals: A two-sided market perspective. American Economic Journal: Microeconomics, 2(2), pp. 222-55.

Larivière, V., Haustein, S. \& Mongeon, P., 2015. The oligopoly of academic publishers in the digital era. PloS one, 10(6), p. e0127502.

Lewis, D. W., 2012. The inevitability of open access. College \& research libraries, 73(5), pp. 493-506.

Liu, L., 2005. Factors determining subscription prices of scholarly journals in business discipline: Themes and variations. Library collections, acquisitions, and technical services, 29(4), pp. 382-394.

McCabe, M., 2002. Journal pricing and mergers: a portfolio approach. American Economic Review, 92(1), pp. 259-269.

McCabe, M., 2004. Information goods and endogenous pricing strategies: The case of academic journals. Economics Bulletin, 12(10), pp. 1-11.

McCabe, M. \& Snyder, C., 2007. Academic journal prices in a digital age: a two-sided market. The BE Journal of Economic Analysis \& Policy, 7(1).

McCabe, M. \& Snyder, C., 2018. Open access as a crude solution to a hold-up problem in the. The Journal of Industrial Economics, 66(2), pp. 301-349.

McVeigh, M. E., 2004. Open access journals in the ISI citation databases: analysis of impact factors and citation patterns: a citation study from Thomson Scientific. Philadelphia: Thomson Scientific.

Miguel, S., Chinchilla-Rodriguez, Z. \& de Moya-Anegón, F., 2011. Open access and Scopus: A new approach to scientific visibility from the standpoint of access. Journal of the American society for information science and technology, 62(6), pp. 1130-1145.

Moed, H. F., 2010. Measuring contextual citation impact of scientific journals. Journal of informetrics, 4(3), pp. 265-277.

Morrison, H., Salhab, J., Calvé-Genest, A. \& Horava, T., 2015. Open access article processing charges: DOAJ survey May 2014. Publications, 3(1), pp. 1-16. 
Pinfield, S., Salter, J. \& Bath, P. A., 2016. The "total cost of publication" in a hybrid open-access environment: Institutional approaches to funding journal article-processing charges in combination with subscriptions. Journal of the Association for Information Science and Technology, 67(7), pp. 1751-1766.

Pinfield, S., Salter, J. \& Bath, P. A., 2017. A “Gold-centric" implementation of open access: Hybrid journals, the "Total cost of publication," and policy development in the UK and beyond. Journal of the Association for Information Science and Technology, 68(9), pp. 2248-2263.

Piwowar, H. et al., 2018. The state of OA: a large-scale analysis of the prevalence and impact of Open Access articles. PeerJ, Volume 6, p. e4375.

Romeu, C. et al., 2014. The SCOAP3 initiative and the Open Access Article-ProcessingCharge market: global partnership and competition improve value in the dissemination of science. s.1., s.n.

Schönfelder, N., 2018. APCs-Mirroring the Impact Factor or Legacy of the SubscriptionBased Model. Bielefeld, Germany: s.n.

Smith, R., 2018. The business of academic publishing:" a catastrophe". Lancet, 392(10154), pp. 1186-1187.

Solomon, D. J., 2013. Types of open access publishers in Scopus. Publications, 1(1), pp. 1626.

Solomon, D. J. \& Björk, B., 2012a. Publication fees in open access publishing: Sources of funding and factors influencing choice of journal. Journal of the American Society for Information Science and Technology, 63(1), pp. 98-107.

Solomon, D. J. \& Björk, B., 2012b. A study of open access journals using article processing charges. Journal of the American Society for Information Science and Technology, 63(8), pp. 1485-1495.

Solomon, D. J., Laakso, M. \& Björk, B.-C., 2013. A longitudinal comparison of citation rates and growth among open access journals. Journal of informetrics, 7(3), pp. 642-650.

Suber, P., 2002 . Open access to the scientific journal literature. Journal of biology, 1(1), pp. 1-3.

Tennant, J. P. et al., 2016. The academic, economic and societal impacts of Open Access: an evidence-based review. F1000Research, p. 5.

Tenopir, C. et al., 2017. Imagining a gold open access future: attitudes, behaviors, and funding scenarios among authors of academic scholarship. College and Research Libraries, 78(6). 
Wang, L. L., Liu, X. Z. \& Fang, H., 2015. Investigation of the degree to which articles supported by research grants are published in open access health and life sciences journals. Scientometrics, 104(2), pp. 511-528.

Whitley, R., 2000. The intellectual and social organization of the sciences. Oxford: Oxford University Press.

Yuen, J., Muquit, S. \& Whitfield, P. C., 2019. "Correlation between cost of publication and journal impact. comprehensive cross-sectional study of exclusively open-access surgical journals. Journal of surgical education, 6(1), pp. 107-119. 


\section{Appendix 1}

The classification of disciplines to fields according to Scopus

\begin{tabular}{|c|c|}
\hline Fields & Disciplines \\
\hline Health Sciences & $\begin{array}{l}\text { Medicine } \\
\text { Nursing } \\
\text { Veterinary } \\
\text { Dentistry } \\
\text { Health Professions } \\
\end{array}$ \\
\hline Life Sciences & $\begin{array}{l}\text { Agricultural and Biological Sciences } \\
\text { Biochemistry; Genetics and Molecular Biology } \\
\text { Immunology and Microbiology } \\
\text { Neuroscience } \\
\text { Pharmacology; Toxicology and Pharmaceutics }\end{array}$ \\
\hline Physical Sciences & $\begin{array}{l}\text { Chemical Engineering } \\
\text { Chemistry } \\
\text { Computer Science } \\
\text { Earth and Planetary Sciences } \\
\text { Energy } \\
\text { Engineering } \\
\text { Environmental Science } \\
\text { Materials Science } \\
\text { Mathematics } \\
\text { Physics and Astronomy }\end{array}$ \\
\hline Social Sciences & $\begin{array}{l}\text { Arts and Humanities } \\
\text { Business; Management and Accounting } \\
\text { Decision Sciences } \\
\text { Economics; Econometrics and Finance } \\
\text { Psychology } \\
\text { Social Sciences }\end{array}$ \\
\hline
\end{tabular}




\section{Diskussionspapiere aus dem Institut für Volkswirtschaftslehre der Technischen Universität IImenau}

Nr. 69 Budzinski, Oliver: Empirische Ex-Post Evaluation von wettbewerbspolitischen Entscheidungen: Methodische Anmerkungen, Januar 2012.

Nr. 70 Budzinski, Oliver: The Institutional Framework for Doing Sports Business: Principles of EU Competition Policy in Sports Markets, January 2012.

Nr.71 Budzinski, Oliver; Monostori, Katalin: Intellectual Property Rights and the WTO, April 2012.

Nr. 72 Budzinski, Oliver: International Antitrust Institutions, Juli 2012.

Nr.73 Budzinski, Oliver; Lindstädt, Nadine: Newspaper vs. Online Advertising - Is There a Niche for Newspapers in Modern Advertising Markets?, Juli 2012a.

Nr.74 Budzinski, Oliver; Lindstädt, Nadine: Newspaper and Internet Display Advertising - Co-Existence or Substitution?, Juli 2012b.

Nr. 75 Budzinski, Oliver: Impact Evaluation of Merger Control Decisions, August 2012.

Nr.76 Budzinski, Oliver; Kuchinke, Björn A.: Deal or No Deal? Consensual Arrangements as an Instrument of European Competition Policy, August 2012.

Nr. 77 Pawlowski, Tim, Budzinski, Oliver: The (Monetary) Value of Competitive Balance for Sport Consumers, Oktober 2012.

Nr.78 Budzinski, Oliver: Würde eine unabhängige europäische Wettbewerbsbehörde eine bessere Wettbewerbspolitik machen?, November 2012.

Nr.79 Budzinski, Oliver; Monostori, Katalin; Pannicke, Julia: Der Schutz geistiger Eigentumsrechte in der Welthandelsorganisation - Urheberrechte im TRIPS Abkommen und die digitale Herausforderung, November 2012.

Nr. 80 Beigi, Maryam H. A.; Budzinski, Oliver: On the Use of Event Studies to Evaluate Economic Policy Decisions: A Note of Caution, Dezember 2012.

Nr. 81 Budzinski, Oliver; Beigi, Maryam H. A.: Competition Policy Agendas for Industrializing Countries, Mai 2013.

Nr.82 Budzinski, Oliver; Müller, Anika: Finanzregulierung und internationale Wettbewerbsfähigkeit: der Fall Deutsche Bundesliga, Mai 2013.

Nr. 83 Doose, Anna Maria: Methods for Calculating Cartel Damages: A Survey, Dezember 2013.

Nr. 84 Pawlowski, Tim; Budzinski, Oliver: Competitive Balance and Attention Level Effects: Theore-tical Considerations and Preliminary Evidence, März 2014. 
Nr. 85 Budzinski, Oliver: The Competition Economics of Financial Fair Play, März 2014.

Nr. 86 Budzinski, Oliver; Szymanski, Stefan: Are Restrictions of Competition by Sports Associations Horizontal or Vertical in Nature?, März, 2014.

Nr. 87 Budzinski, Oliver: Lead Jurisdiction Concepts Towards Rationalizing Multiple Competition Policy Enforcement Procedures, Juni 2014.

Nr. 88 Budzinski, Oliver: Bemerkungen zur ökonomischen Analyse von Sicherheit, August 2014.

Nr. 89 Budzinski, Oliver; Pawlowski, Tim: The Behavioural Economics of Competitive Balance: Implications for League Policy and Championship Management, September 2014.

Nr.90 Grebel, Thomas; Stuetzer, Michael: Assessment of the Environmental Performance of European Countries over Time: Addressing the Role of Carbon Leakage and Nuclear Waste, September 2014.

Nr. 91 Emam, Sherief; Grebel, Thomas: Rising Energy Prices and Advances in Renewable Energy Technologies, July 2014.

Nr.92 Budzinski, Oliver; Pannicke, Julia: Culturally-Biased Voting in the Eurovision Song Contest: Do National Contests Differ?, December 2014.

Nr. 93 Budzinski, Oliver; Eckert, Sandra: Wettbewerb und Regulierung, März 2015.

Nr. 94 Budzinski, Oliver; Feddersen, Arne: Grundlagen der Sportnachfrage: Theorie und Empirie der Einflussfaktoren auf die Zuschauernachfrage, Mai 2015.

Nr.95 Pannicke, Julia: Abstimmungsverhalten im Bundesvision Song Contest: Regionale Nähe versus Qualität der Musik, Oktober 2015.

Nr. 96 Budzinski, Oliver; Kretschmer, Jürgen-Peter: Unprofitable Horizontal Mergers, External Effects, and Welfare, October 2015.

Nr.97 Budzinski, Oliver; Köhler, Karoline Henrike: Is Amazon The Next Google?, October 2015.

Nr.98 Kaimann, Daniel; Pannicke, Julia: Movie success in a genre specific contest: Evidence from the US film industry, December 2015.

Nr. 99 Pannicke, Julia: Media Bias in Women's Magazines: Do Advertisements Influence Editorial Content?, December 2015.

Nr. 100 Neute, Nadine; Budzinski, Oliver: Ökonomische Anmerkungen zur aktuellen Netzneutralitätspolitik in den USA, Mai 2016. 
Nr. 101 Budzinski, Oliver; Pannicke, Julia: Do Preferences for Pop Music Converge across Countries? - Empirical Evidence from the Eurovision Song Contest, Juni 2016.

Nr. 102 Budzinski, Oliver; Müller-Kock, Anika: Market Power and Media Revenue Allocation in Professonal Sports: The Case of Formula One, Juni 2016.

Nr. 103 Budzinski, Oliver: Aktuelle Herausforderungen der Wettbewerbspolitik durch Marktplätze im Internet, September 2016.

Nr. 104 Budzinski, Oliver: Sind Wettbewerbe im Profisport Rattenrennen?, Februar 2017.

Nr. 105 Budzinski, Oliver; Schneider, Sonja: Smart Fitness: Ökonomische Effekte einer Digitalisierung der Selbstvermessung, März 2017.

Nr. 106 Budzinski, Oliver; Pannicke, Julia: Does Popularity Matter in a TV Song Competition? Evidence from a National Music Contest, April 2017.

Nr. 107 Budzinski, Oliver; Grusevaja, Marina: Die Medienökonomik personalisierter Daten und der Facebook-Fall, April 2017.

Nr. 108 Budzinski, Oliver: Wettbewerbsregeln für das Digitale Zeitalter - Die Ökonomik personalisierter Daten, Verbraucherschutz und die 9.GWB-Novelle, August 2017.

Nr. 109 Budzinski, Oliver: Four Cases in Sports Competition Policy: Baseball, Judo, Football, and Motor Racing, September 2017.

Nr. 110 Budzinski, Oliver: Market-internal Financial Regulation in Sports as an Anticompetitive Institution, October 2017.

Nr. 111 Bougette, Patrice; Budzinski, Oliver; Marty, Frédéric: EXPLOITATIVE ABUSE AND ABUSE OF ECONOMIC DEPENDENCE: WHAT CAN WE LEARN FROM THE INDUSTRIAL ORGANIZATION APPROACH?, December 2017.

Nr. 112 Budzinski, Oliver; Gaenssle, Sophia: The Economics of Social Media Stars: An Empirical Investigation of Stardom, Popularity, and Success on YouTube, Januar 2018.

Nr. 113 Gaenssle, Sophia; Budzinski, Oliver; Astakhova Daria: Conquering the Box Office: Factors, influencing Success of International Movies in Russia, Mai 2018.

Nr.114 Budzinski, Oliver; Stöhr, Annika: Die Ministererlaubnis als Element der deutschen Wettbewerbsordnung: eine theoretische und empirische Analyse, Juli 2018.

Nr. 115 Budzinski, Oliver; Kuchinke, Björn A.: Modern Industrial Organization Theory of Media Markets and Competition Policy Implications, September 2018.

Nr. 116 Budzinski, Oliver; Lindstädt-Dreusicke, Nadine: The New Media Economics of Video-on-Demand Markets: Lessons for Competition Policy, Oktober 2018. 
Nr. 117 Budzinski, Oliver; Stöhr, Annika: Competition Policy Reform in Europe and Germany - Institutional Change in the Light of Digitization, November 2018.

Nr. 118 Budzinski, Oliver; Noskova, Victoriia; Zhang, Xijie: The Brave New World of Digital Personal Assistants: Benefits and Challenges from an Economic Perspective, December 2018.

Nr.119 Bougette, Patrice; Budzinski, Oliver \& Marty, Frédéric: EXPLOITATIVE ABUSE AND ABUSE OF ECONOMIC DEPENDENCE: WHAT CAN WE LEARN FROM AN INDUSTRIAL ORGANIZATION APPROACH? [Updated Version 2018], December 2018.

Nr. 120 Bartelt, Nadja: Bundling in Internetmärkten - Ökonomische Besonderheiten, Wettbewerbseffekte und Regulierungsimplikationen, Dezember 2018.

Nr. 121 Budzinski, Oliver; Feddersen, Arne: Measuring Competitive Balance in Formula One Racing, März 2019.

Nr. 122 Budzinski, Oliver; Kohlschreiber, Marie; Kuchinke, Björn A. \& Pannicke, Julia: Does Music Quality Matter for Audience Voters in a Music Contest, März 2019.

Nr. 123 Gaenssle, Sophia; Budzinski, Oliver: Stars in Social Media: New Light Through Old Windows?, April 2019.

Nr. 124 Stöhr, Annika; Budzinski, Oliver: Ex-post Analyse der Ministererlaubnis-Fälle Geminwohl durch Wettbewerbsbeschränkungen?, April 2019.

Nr. 125 Budzinski, Oliver; Lindstädt-Dreusicke, Nadine: The New Media Economics of Video-on-Demand Markets: Lessons for Competition Policy (Updated Version), May 2019.

Nr. 126 Stöhr, Annika; Noskova, Victoriia; Kunz-Kaltenhäuser, Philipp; Gaenssle, Sophia \& Budzinski, Oliver: Happily Ever After? - Vertical and Horizontal Mergers in the U.S. Media Industry, June 2019.

Nr. 127 Budzinski, Oliver; Stöhr, Annika: Der Ministererlaubnis-Fall Miba/Zollern: Europäische Champions statt Wettbewerb?, Juni 2019.

Nr. 128 Budzinski, Oliver; Gaenssle, Sophia \& Kunz-Kaltenhäuser, Philipp: How Does Online Streaming Affect Antitrust Remedies to Centralized Marketing? The Case of European Football Broadcasting, Rights, July 2019.

Nr. 129 Budzinski, Oliver; Haucap, Justus: Kartellrecht und Ökonomik: Institutions Matter!, Juli 2019.

Nr. 130 Budzinski, Oliver \& Stöhr, Annika: Public Interest Considerations in European Merger Control Regimes, August 2019.

Nr. 131 Gaenssle, Sophia; Budzinski, Oliver \& Astakhova: Daria: Conquering the Box Office: Factors Influencing Succes of International Movies in Russia (Update), October 2019. 
Nr.132 Stöhr, Annika; Budzinski, Oliver \& Jasper, Jörg: Die Neue E.ON auf dem deutschen Strommarkt - Wettbewerbliche Auswirkungen der innogy-Übernahme, November 2019.

Nr. 133 Budzinski, Oliver; Grebel, Thomas; Wolling, Jens \& Zhang, Xijie: Drivers of Article Processing Charges in Open Access, December 2019.

Nr. 134 Gaenssle, Sophia; Kuchinke, Björn, A.: Die Hörspielserie „Die drei ???“ - Der wirtschaftliche Erfolg und Gründe dafür, Januar 2020.

Nr. 135 Budzinski, Oliver: The Economics of International Competition Policy: New Challenges in the Light of Digitization?, January 2020.

Nr. 136 Dittmann, Heidi \& Kuchinke, Björn A.: Die Theorie mehrseitiger Marktplätze in der US-amerikanischen und deutschen Zusammenschlusskontrolle: Eine empirische Untersuchung für den Mediensektor, Januar 2020.

Nr. 137 Budzinski, Oliver; Gaenssle, Sophia \& Lindstädt-Dreusicke, Nadine: The Battle of YouTube, TV and Netflix - An Empirical Analysis of Competition in Audiovisual Media Markets, April 2020.

Nr. 138 Gaenssle, Sophia \& Kunz-Kaltenhäuser, Philipp: What Drives Binge-Watching? An Economic Theory and Analysis of Impact Factors, April 2020.

Nr. 139 Budzinski, Oliver; Grusevaja, Marina \& Noskova, Victoriia: The Economics oft he German Investigation of Facebook's Data Collection, May 2020.

Nr. 140 Budzinski, Oliver; Gaenssle, Sophia \& Stöhr, Annika: Der Entwurf zur 10. GWB Novelle: Interventionismus oder Laissezfaire?, Juni 2020.

Nr. 141 Budzinski, Oliver \& Kunz-Kaltenhäuser, Philipp: Promoting or Restricting Competition? - The 50plus1-Rule in German Football, June 2020.

Nr. 142 Budzinski, Oliver; Gaenssle, Sophia \& Stöhr, Annika: The Draft for the $10^{\text {th }}$ Amendment of German Competition Law: Towards a new Concept of „Outstanding Relevance across Markets"?, June 2020.

Nr. 143 Budzinski, Oliver \& Stöhr, Annika: Ministererlaubnis für Kartellfälle: Kooperation im Sinne des Gemeinwohls?, August 2020.

Nr. 144 Gaenssle, Sophia: Big Data Comes to Hollywood - Audiovisuelle Medienmärkte im Digitalen Zeitalter, August 2020. 